\title{
Effectiveness of Archives Management Reviewed from Management Factors in Pattallassang Sub-District Office in Gowa regency
}

\author{
Henni Zainal ${ }^{1}$, Andi Idham Ashar ${ }^{2}$, Andi Tenry Sose ${ }^{3}$, Darmawati Manda ${ }^{4}$, Ignasius \\ Setitit $^{5}$ \\ Universitas Indonesia Timur, Makassar ${ }^{1}$ \\ Universitas Bosowa, Makassar ${ }^{2,4}$ \\ Stim Lasharan Jaya, Makassar ${ }^{3}$ \\ STIA Trinitas Ambon ${ }^{5}$ \\ Email: henni_zainal@yahoo.com ${ }^{1}$, andiidham31@yahoo.co.id ${ }^{2}$, tenrysose@yahoo.com ${ }^{3}$, \\ darmawati.manda@universitasbosowa.ac.id ${ }^{4}$, ignasius_seti@yahoo.com ${ }^{5}$
}

(Received: 28 July 2020; revised: 14 August 2020; published: 23 September 2020)

\begin{abstract}
Archives has a role as a center of memory, resources and as a necessary means of supervision in every organization in order to carry out all its activities both in the offices of state and private institutions. The purpose of this research is to find out the management of archives reviewed from management factors in the District Office Pattallassang Gowa Regency.The research method used is qualitative by survey method, namely research that intends to obtain facts from the phenomena in order to understand and solve problems related to factors that affect the effectiveness of archive management in the District Office Pattallassang Gowa Regency. Data collection techniques used are observations, documentations and interviews. Conclusion in this research is a management factor, it is expected to do the purging of archives above 5 years with clear recording and supervision and evaluation of activities after the activity in order to know the advantages and disadvantages of the activity so that the next activities can be maximized better.
\end{abstract}

Keyword : Effectiveness, Management, Archives, Management.

\section{INTRODUCTION}

Archives has a role as a center of memory, resources and as a necessary means of supervision in every organization in order to carry out all its activities both in the offices of state and private institutions (Zulkifli., 1996). In the process of presenting information so that the leadership can make decisions and plans policies, then there must be a good system and working procedures from the description above it appears that the importance of archives turns out to have a extensive range of archives such as a center role of memory, information sources and as a means of supervision that is very in the field of archives.An institution be it a state or private institution will not be able to provide good information, complete and accurate data, if the institution does not have good and regular archives management.Archives can be said to be a system in which each other is related in one whole bond, because the archive can support a program of organizational activities, both in terms of planning, implementation and control of the duties of the organization concerned (Henni Zainal, Parinsi, Indonesia, Hasan, \& Makassar, 2018; Tri 
Wartono, 2017; Zainal \& Farwita, 2019). In addition, adequate facilities and infrastructure are needed for the storage and security of archives.

Law of the Republic of Indonesia Number 43 year 2009 concerning Archival explained that the meaning of archival is matters relating to archives while the meaning of archives is recordings of activities or events in various forms and media in accordance with the development of information and communication technology made and received by state institutions, local governments, educational institutions, companies, political organizations, community organizations and individuals in the implementation of social life, nation, and statehood.

In article 3 of Law No.43 of 2009, among others, it is formulated that the purpose of archival implementation is: (a) ensuring the creation of archives of activities carried out by state institutions, local governments, educational institutions, corporations, political organizations, community and individual organizations, and ANRI as the organizer of national archives, (b) guarantee the availability of authentic and reliable archives as a legal evidence tool, (c) ensure the realization of reliable records management and utilization of archives in accordance with the provisions of the legislation, (d) guarantee the protection of state interests and civil rights of the people through the management and utilization of authentic and reliable records, (e) to serve the implementation of national archives as a comprehensive and integrated system, (f) ensuring the safety and security of archives as evidence of accountability in the life of society, nation and state, (g) ensuring the safety of national assets in the fields of economic, social, cultural politics, defense, and security as the identity and identity of the nation and (h) improving the quality of public services in the management and utilization of authentic trutsworthy archives ("Badan Arsip dan Perpustakaan Daerah Provinsi Sulawesi Selatan. 2003-2008. Rencana Strategi (RENSTRA). Makassar.," n.d.; Basuki Sulityo, 2008; Budiman Muhammad Rosyid, 2009).

Based on the country's archival laws, the author concludes that the effectiveness of archival management can be measured through three main factors, namely: management factors (planning, organizing, actuanting and controling), facilities and infrastructure factors (minimum standards of archive storage buildings, minimum standards of archive storage and security and archive safety) and leadership factors (direction, communication, decision making and motivation).

Management is an art of directing others to achieve the main goals in an organization through the process of planning, organizing, and managing human resources in an effective and efficient way.According to George R.Terry (1997) management is a different process consisting of planning, organizing, actuating, and controlling carried out to achieve the specified goals by using humans and other resources.Based on the above defenition, the author concluded that the understanding of management is connected with archives is the process of setting up offices related to all forms of letters or documents and manuscripts aimed at facilitating easier document tracing when needed.Therefore, in the implementation of an archival management manager must be able to manage all elements involved in the process of managing archives so that office work is achieved easily, effectively, and efficiently (Atmosudirdjo, 1997; Gibson, 2003; Kusdi, 2009; Palan., 2007).

Management as an activity and the ability to direct and organize work in an organization has a very important role in order to actualize effective and efficient records management (Basuki 
Sulityo, 2008; Budiman Muhammad Rosyid, 2009; Sakur, 2011; Sri Andika Putri, 2017; Zulkifli., 1996).

Management functions such as planning, organizing, resource management, and supervision need to be implemented so that organizational goals and objectives can be achieved.

a) Planning is a fairly important aspect in carrying out an activity.Without a good planning , an activity will not run smoothly .Likewise in the activities of the management of archives at the office. Aspects of planning in the management of archives are indispensable including planning what archives really need to be created, how to provide the services of the archive in order to meet the needs in the implementation of efficiency, wich archives need to be destroyed and also preserved.

b) Organizing, Activities in the field of Planning will not run well if it is not supported by coordination from various components in archives management, Organizing is a followup to a plan.Because planning without concrete steps is a futile plan. Thus, coordination measures in the management of archives.

c) Actuating includes control from the creation of archives to the destruction or preservation including problems of archival maintenance, through careful and directed supervision.

d) Controling includes supervision of all components of archives management so that it is implemented in accordance with standards and effective and efficiently. The success and failure of archival management can be seen in this aspect, because this activity is an evaluation of the management of archives (G. Terry, 2013).

\section{RESEARCH METHODS}

The research method used is qualitative by survey method (Sugiyono, 2010), which is research that intends to obtain facts from the phenomena in order to understand and solve problems related to factors that affect the effectiveness of archive management in pattallassang sub-district office in Gowa regency.Data collection techniques used are observations, documents and interviews.

\section{RESEARCH RESULTS AND DISCUSSION}

Management is an archival process in the District Office Pattallassang Gowa Regency, one of the indicators is Planning : Covering how to provide archival services in the District Office Pattallasssang Gowa in order to meet the needs in the implementation of efficiency, why archives need to be destroyed and also preserved.1). Planning is carried out before the activity is implemented . From the survey conducted to 33 respondents obtained results that $75.76 \%$ of respondents think that every activity done in the District Office Pattallassang Gowa always have a mature planning before the activities are carried out and $24.24 \%$ of respondents also believed the activities are not planned before it was implemented. 
Participants Responses to The Effectiveness of Archives Management Reviewed by Planning Factors

Pattallassang sub-district office in Gowa regency

\begin{tabular}{|c|c|c|c|c|}
\hline \multicolumn{5}{|c|}{ Mature planning before the activities are carried out } \\
\hline Alternative Answer & Score & Frequence & Total & Percentage $(\%)$ \\
\hline ALWAYS & 3 & 25 & 75 & 75,76 \\
\hline NOT ALWAYS & 2 & 8 & 16 & 24,24 \\
\hline NEVER & 1 & 0 & 0 & 0,00 \\
\hline TOTAL & & 33 & 91 & 100 \\
\hline
\end{tabular}

Source : Questionnaire Accumulation Results, Processed in 2018.

Before conducting an activity in the sub-district office, a thorough planning is carried out before the activity is implemented if it is not constrained by the agreed time target.From the observations, researchers found that every activity planning in the district office Pattallassang Gowa regency were carried out by the Head of the Sub-District and participants of the activities concerned.However, if the activity is not very important then planning is carried out by the head of the sub-district, or sub-district secretary along with the head of the section and the head of the sub-section who will follow up the activity.

Each activity is accompanied by an archive of incoming and outgoing letters and documentation of activities stored as physical evidence. However, some activities do not have documentation due to conditions during the activity.From the observations of researchers found that each activity there is an entry letter as an order for the implementation of activities and an exit letter as approval and follow-up of the implementation of activities.Accompanied by a photo documentation of the activities carried out. Such archives and documentation are stored as physical evidence of activity, stored both physically and digitally stored on the computer.

Any activities that have been planned will be coordinated by the chairman of the committee or the person in charge of the activities that will be reported to the head of the subdistrict as the supervisor of the activity.The activity will be reported about the smoothness or not of an activity and the constraints found during the activity.From the observations of researchers found a clear actunting on the procurement of office goods. However, for the destruction of archives that should be carried out in accordance with Law No. 43 of 2009 Archives above 5 years must be destroyed, not done in the District Office Pattallassang Gowa Regency. Pattallassang Sub-District Office of Gowa Regency conducted supervision and evaluation of work by conducting an evaluation meeting of activities and accountability report from the chairman of the committee concerned.Discusses the constraints during the activities and financial accountability that has been used during the activities.

\section{CONCLUSION}

Conclusion in this research is a management factor, it is expected to do the destruction of archives above 5 years with clear recording and conduct supervision (controling) and evaluation of activities after it was done in order to know the advantages and disadvantages of the activity so that the next activities can be maximized better.Each activity have an entry letter as an order for the implementation and an exit letter as approval and follow-up of the implementation 
Accompanied by a photo documentation of the activities carried out. Such archives and documentation are stored as physical evidence of activity, both stored physically and digitally st on the computer.

\section{BIBLIOGRAPHY}

Atmosudirdjo, S. (1997). Organisasi dan Manajemen. Jakarta: PT Guung Agung.

Badan Arsip dan Perpustakaan Daerah Provinsi Sulawesi Selatan. 2003-2008. Rencana Strategi (RENSTRA). Makassar. (n.d.).

Basuki Sulityo. (2008). Manajemen Arsip Dinamis: Pengantar Memahami dan Mengelola Informasi dan Dokumen. Jakarta: Gramedia.

Budiman Muhammad Rosyid. (2009). Dasar Pengelolaan Arsip Elektronik. Yogyakarta: Badan Perpustakaan dan Arsip Daerah.

Gibson, J. . (2003). Struktur Organisasi dan Manajemen. Jakarta: Erlangga.

Henni Zainal, U. I. T., Parinsi, W. K., Indonesia, S. P., Hasan, M., \& Makassar, U. N. (2018). The Influence Of Strategic Assets And Market Orientation To The Performance Of Family Business In Makassar City, Indonesia, 17(6), 1-9.

Kusdi. (2009). Teori Organisasi dan Administrasi. Jakarta: Salemba Humanika.

Palan. (2007). Competency management: Teknis Mengimplementasikan Manajemen Sumber Daya Manusia Berbasis Kompetensi Untuk Meningkatkan Daya Saing Organisasi. Yogyakarta: Salemba Empat.

Sakur. (2011). Kajian Faktor-Faktor yang Mendukung Pengembangan Usaha Mikro Kecil dan Menengah : Studi Kasus di Kota Surakarta Supporting Factors of Usaha Mikro Kecil Dan Menengah ( UMKM ) Development : A. Spirit Publik, 7, 85-109.

Sri Andika Putri. (2017). Pengaruh pelatihan dan kalimat motivasi terhadap produktifitas kerja karyawan umkm. OPTIMA, l(1).

Sugiyono. (2010). Metode Penelitian Pendidikan Pendekatan Kuantitatif, kualitatif, dan R\&D. Bandung: Alfabeta.

Terry, G. (2013). Prinsip- Prinsip Manajemen. Jakarta: PT Bumi Aksara.

Terry, G. R. (1997). Prinsip-Prinsip Manajemen. Jakarta: Bumi Aksara.

Tri Wartono. (2017). Pengaruh stres kerja terhadap kinerja karyawan. Jurnal Ilmiah Prodi Manajemen Universitas Pamulang, 4(2), 41-55.

Zainal, H., \& Farwita, S. (2019). An Analysis of Customer Satisfaction in Ambon City Water Supply Company, (Iconetos), 65-71.

Zulkifli., A. (1996). Pengertian, Fungsi dan Tujuan Arsip. Jakarta: PT. Gramedia Pustaka Utama. 